\title{
Dietary Supplementation with Sesame Seeds to Improve Semen Quality of Ho Cocks
}

\author{
Nguyen Thi Xuan, Nguyen Van Duy, Dang Thuy Nhung \& Vu \\ Dinh Ton
}

Faculty of Animal Science, Vietnam National University of Agriculture, Hanoi 131000, Vietnam

\begin{abstract}
High levels of polyunsaturated fatty acids in chicken spermatozoa make them susceptible to lipoperoxidation and reduce their fertility. This study was conducted to assess the effect of sesame seed suplementation in the diet on the semen quality of Ho cocks. Eighteen 13-14 month-old cocks were randomly divided into three groups and were assigned to one of the following treatments: $0 \% \mathrm{SS}$ (control), 5\% SS, or 7\% sesame seeds per $\mathrm{kg}$ of diet for ten consecutive weeks after a two-week adaptation period. Semen characteristics were evaluated once a week. In the $7 \%$ sesame seed treatment group, seminal traits including semen ejaculate volume $(1.02 \mathrm{~mL})$, sperm concentration $\left(3.68 \times 10^{9}\right.$ sperm), and abnormal spermatozoa $(10.51 \%$ were improved $(\mathrm{P}<0.05)$ compared to the control group $\left(0.82 \mathrm{~mL}, 2.81 \times 10^{9}\right.$ sperm, and $11.04 \%$ for semen ejaculate volume, sperm concentration, and abnormal spermatozoa, respectively). Supplementation with sesame seeds did not significantly affect sperm motility, mass movement, or semen $\mathrm{pH}$. Our results demonstrate that sesame seed supplementation at $7 \%$ successfully improved the ejaculate volume, sperm concentration, and normal spermatozoa percentage of Ho cocks.
\end{abstract}

\section{Keywords}

Semen quality, Ho cock, sesame seed supplementation

Received: Febuary 21, 2019

Accepted: May 14, 2019

\section{Introduction}

In Vietnam, the national poultry flock is dominated by local breeds. Among indigenous chicken breeds in Vietnam, the Ho chicken breed is famous for its massive body weight $(3.78 \mathrm{~kg}$ per cock and 2.64kg per hen) (Duy et al., 2015). However, this heavy body weight leads to their poor natural mating ability and hence, a low rate of fertile eggs $(72.81 \%$ ) (Duy et al., 2015). In addition, semen production and quality of Ho cocks are considered as poor. Hue et al. (2015) reported that the semen qualities of Ho cocks in terms of average ejaculate volume, motility, and sperm 
concentration were $0.63 \mathrm{~mL}, 57.6 \%$, and 950.6 million sperms $\mathrm{mL}^{-1}$, and feeding strategies to improve the fertility of Ho chicken flocks have been increasing in recent years.

Avian spermatozoa are susceptible to peroxidative damage due to the high amount of long-chain polyunsaturated fatty acids (PUFA) within the membrane phospholipids (Jafari et $a l ., 2013)$. This can result in decreased fertility. Nutritional supplements may have an influence on the oxidative attacks (Min et al., 2016). Recent studies have shown that dietary supplementation with antioxidants such as vitamin $\mathrm{E}$ and vitamin $\mathrm{C}$ could improve the reproductive performance of chickens (Biswas et al., 2009; Ebeid, 2012; Min et al., 2016). Sesame seeds are highly resistant to oxidative deterioration and is the oldest oilseed used to treat male fertility (Abou-Gharbia et al., 2000; Dimitrios, 2006). The strong antioxidant activity of sesame is due to its high levels of bioactive components including lignans sesamin and sesamolin (Abou-Gharbia et al., 2000; Shittu \& Bankole, 2007; Pathak et al., 2014; Gharby et al., 2017), copper and calcium, phosphorous, iron, magnesium, manganese, zinc, and vitamin B1 (Pathak et al., 2014; Gharby et al., 2017). The main unsaturated fatty acids of sesame seeds are linoleic acid (37-47\%), oleic acid (35$43 \%$ ), palmitic (9-11\%), and stearic acid (5$10 \%$ ) (Pathak et al., 2014). Moreover, sesame contains other lignans including sesaminol, sesangolin, and 2-episalatin that have antioxidant properties (Dimitrios, 2006).

To the best of our knowledge, the effect of sesame seeds on the semen quality of Ho chickens has never been investigated. Therefore, the objective of this study was to assess the impact of sesame seed dietary supplementation on the semen quality parameters of Ho cocks.

\section{Materials and Methods}

This study was implemented at the chicken farm of the Faculty of Animal Science, Vietnam National University of Agriculture.

\section{Experimental design, animals, and housing}

A total of 18 sexually mature and clinically healthy Ho chicken breeder males, which were 13-14 months old and had an average body weight of $3.73 \pm 0.47 \mathrm{~kg}$ per animal, were assigned to three treatments, comprised of diets containing different ratios of sesame seeds, namely $0 \%, 5 \%$, and $7 \%$, taking into account body weight. There were six replicates per treatment. The length of the adaptation period was 14 days, followed by an experimental period of 70 days. The cocks were housed individually in $1 \times 1 \times 1 \mathrm{~m}$ cages with solid concrete floors and rice hull bedding. The photoperiod was $16 \mathrm{~h}$ of light per day. All the necessary vaccinations and medications were administered accordingly.

\section{Experimental diets and feeding}

Three different diets were formulated for this experiment (Table 1). The dietary treatments were corn-soybean-rice bran based diets supplemented with $0 \%, 5 \%$, and $7 \%$ sesame seeds (denoted as control, $5 \% \mathrm{SS}$, and $7 \%$ SS, respectively). Sesame seeds were purchased from a local farmer in Thua Thien Hue province. Proximate analysis of the sesame seeds showed that they contained $5.96 \%$ humidity, $4121 \mathrm{Kcal} \mathrm{kg}^{-1}, 21.63 \%$ crude protein, $45.60 \%$ crude lipid, $15.21 \%$ crude fiber, and $5.44 \%$ ash. The sesame seeds were incorporated into the diet by replacing equivalent amounts of soybean seeds. Minor adjustments were made in the ingredients to keep the diets isonitrogenous and isocaloric. The feed was served twice per day and water was provided ad-libitum.

\section{Semen collection and characterization}

Semen was collected from the cockerels once a week using the dorso-abdominal massage, a modified technique as described by Lake (1962). Semen was collected into $1.5 \mathrm{~mL}$ Eppendorf tubes. After ejaculate collection, semen samples were stored at $4-10^{\circ} \mathrm{C}$ and examined for the following traits: (1) Ejaculate volume $(\mathrm{mL})$ from individual cocks was measured visually with the use of a prepared clean graduated collection tube; (2) Semen $p H$ was determined by using $\mathrm{pH}$ test strips; and (3) Concentration of spermatozoa was measured 
Table 1. Ingredients and the chemical composition of the experimental diets fed to the Ho cocks (DM basis)

\begin{tabular}{|c|c|c|c|}
\hline Diets & $\begin{array}{l}\text { Control } \\
(0 \% \text { SS) }\end{array}$ & $5 \%$ SS & $7 \%$ SS \\
\hline \multicolumn{4}{|l|}{ Ingredients (\%) } \\
\hline Yellow corn & 58 & 58 & 56 \\
\hline Full-fat soybean & 15 & 15 & 15 \\
\hline Rice bran & 8 & 8 & 8 \\
\hline DDGS & 6.9 & 6.9 & 6.9 \\
\hline Fish meal & 2 & 2 & 2 \\
\hline Limestone & 1.5 & 1.5 & 1.5 \\
\hline Dicalcium phosphate (DCP) & 1.8 & 1.8 & 1.8 \\
\hline Salt & 0.2 & 0.2 & 0.2 \\
\hline Premix vit.mineral & 1 & 1 & 1 \\
\hline Methionine & 0.2 & 0.2 & 0.2 \\
\hline Lysine & 0.4 & 0.4 & 0.4 \\
\hline Roasted sesame seeds & 0 & 5 & 7 \\
\hline Roasted soybean seeds & 5 & 0 & 0 \\
\hline Total & 100 & 100 & 100 \\
\hline \multicolumn{4}{|l|}{ Proximate chemical compositions } \\
\hline Humidity (\%) & 9.14 & 8.87 & 8.62 \\
\hline ME (Kcal kg-1) & 2800 & 2810 & 2830 \\
\hline Crude protein (\%) & 16.97 & 17.05 & 17.10 \\
\hline Crude lipid (\%) & 5.60 & 5.72 & 5.94 \\
\hline Crude fiber (\%) & 5.52 & 5.79 & 6.01 \\
\hline $\mathrm{Ca}(\%)$ & 1.15 & 1.15 & 1.16 \\
\hline $\mathrm{P}(\%)$ & 0.82 & 0.86 & 0.90 \\
\hline
\end{tabular}

Note: $S S=$ Sesame seed, DDGS = Distillers dried grains with solubles, ME = Metabolizable energy .

by implementing the direct cell count method. A Neubauer chamber, which is used for counting blood cells, was used to measure the concentration of spermatozoa. Five $\mu \mathrm{L}$ of semen was mixed with $495 \mu \mathrm{L}$ of saline solution $(3 \%$ $\mathrm{NaCl}$ ). Ten $\mu \mathrm{L}$ of the diluted semen was then placed on one end of the hemocytometer using a micropipette and also on the other end to settle. The loaded hemocytometer was then placed on a microscope at a magnification of 40x. The heads of spermatozoa that fell within the subdivided smaller squares at the four edges and center of the hemocytometer were counted. The average sperm count per individual was calculated from two repeated measurements. The concentration of sperm per volume was estimated using the formula: $\mathrm{C}=\mathrm{N} \times 5 \times 10^{6}$, where: $\mathrm{C}$ is the concentration of spermatozoa per volume (sperm count $\mathrm{mL}^{-1}$ ), and $\mathrm{N}$ is the number of spermatozoa counted.

To assess mass motility of sperm (\%), a drop of semen was placed on a microscope slide using a micropipette, and then covered with a glass coverslip to spread the semen in order to have a uniform thickness and to prevent drying. Thereafter, it was placed on a microscope with a magnification of $40 \mathrm{x}$ for examination. The 
motility determination of the semen sample was expressed as the percentage of sperm cells showing forward motion, under their own power (Ax et al., 2000). Sperm motility was also scored to assess mass movement, aspects of wave motion. The score was assigned between 0 (total sperm are motionless) and 5 (wave motion varied rapidly, eddies are present) (Sonseeda $e t$ al., 2013).

The percentage of abnormal sperm was determined by using a $2 \%$ eosin stain. A drop of fresh semen was mixed with a drop of eosin stain on a glass slide followed by making a thin smear of it. The spermatozoa were examined under a digital camera (Optilab, Miconos, Indonesia) connected to a conventional microscope (Ceti, Belgium) and a computer at 40x magnification. At least 200 live spermatozoa were counted to determine the percentage of abnormal sperm according to Abu et al. (2013) and Bah et al. (2001). The dead spermatozoa were stained with eosin and appeared pink in color, while the live spermatozoa were not stained with eosin and appeared without any color. Spermatozoa with spindle-shaped heads and visible tails were considered as normal, while spermatozoa with structural defects, e.g. a simple bend at the midpiece, coiled head, broken tail, loose head, or tail coiled below the head of the spermatozoa, were considered abnormal (Figure 1).

\section{Statistical analysis}

Data were analyzed using Microsoft Excel (2016) and Minitab software version 16.1.0 (2010 Minitab Inc.). The overall means of the semen quality characteristics were expressed as the means and standard error (SE) of the means. One-way analysis of variance (ANOVA) was used to compare means with the Tukey test. Pvalues of $<0.05$ were considered statistically significant.

\section{Results and Discussion}

\section{Semen quality characteristics during the adaptation period}

The semen quality characteristics of the Ho cocks in the three treatment groups were similar during the adaptation period (Table 2).

\section{Semen ejaculate volume}

The semen ejaculate volume showed similar values $(0.64-0.73 \mathrm{~mL})$ in the control, $5 \% \mathrm{SS}$, and $7 \%$ SS groups during the adaptation period. These values are proportional to the results of Hue et al. (2015) and Xuan et al. (2017) who reported that the average ejaculate volumes of Ho cocks were 0.63 and $0.70 \mathrm{~mL}$, respectively. Almahdi et al. (2014) and Masindi \& Mphaphathi (2016) recorded that the average ejaculate volume of Venda cockerels (a local chicken breed from South Africa with a low

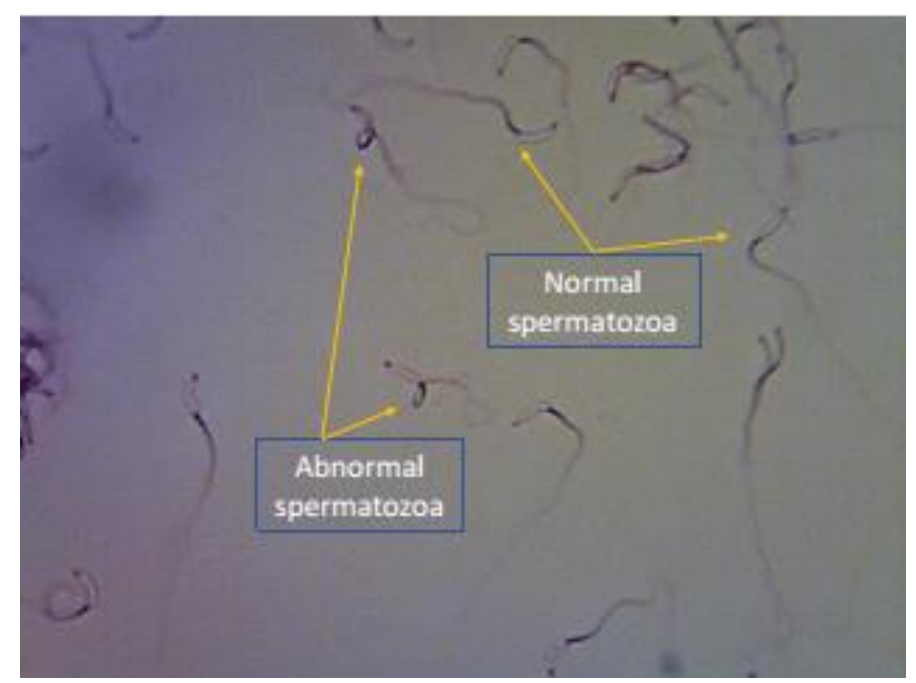

Figure 1. Photomicrography of Ho cock spermatozoa under a digital camera (Optilab, Miconos, Indonesia) connected to a conventional microscope (Ceti, Belgium) and a computer at 40x magnification 
Table 2. Semen quality characteristics during the adaptation period

\begin{tabular}{|c|c|c|c|c|c|c|c|}
\hline \multirow[t]{2}{*}{ Parameter } & \multicolumn{2}{|c|}{$\begin{array}{l}\text { Control } \\
(n=12)\end{array}$} & \multicolumn{2}{|c|}{$\begin{array}{l}5 \% \text { SS } \\
(n=12)\end{array}$} & \multicolumn{2}{|c|}{$\begin{array}{l}7 \% \text { SS } \\
(n=12)\end{array}$} & \multirow[t]{2}{*}{ P-value } \\
\hline & Mean & SE & Mean & SE & Mean & SE & \\
\hline Semen volume $(\mathrm{mL})$ & 0.64 & 0.11 & 0.67 & 0.06 & 0.73 & 0.06 & 0.63 \\
\hline Sperm concentration $\left(10^{9}\right.$ sperm $\left.\mathrm{mL}^{-1}\right)$ & 1.81 & 0.18 & 2.19 & 0.21 & 1.95 & 0.14 & 0.60 \\
\hline Sperm motility (\%) & 70.00 & 5.27 & 67.50 & 4.15 & 69.38 & 3.57 & 0.95 \\
\hline Mass movement & 3.08 & 0.13 & 2.86 & 0.23 & 3.01 & 0.18 & 0.85 \\
\hline Semen $\mathrm{pH}$ & 7.52 & 0.13 & 7.63 & 0.08 & 7.68 & 0.05 & 0.64 \\
\hline Abnormal spermatozoa (\%) & 10.95 & 0.12 & 10.90 & 0.16 & 11.42 & 0.28 & 0.37 \\
\hline
\end{tabular}

reproductive potential) and Arabic cockerels (an indigenous chicken from Europe) were both $0.3 \mathrm{~mL}$. Differences in the live body weights of the mature cocks, which were around $3.7 \mathrm{~kg}$ in the Ho breed, $2.3 \mathrm{~kg}$ in the Venda breed, and $1.65 \mathrm{~kg}$ in the Arabic breed, may account for the substantial variation in ejaculate volume.

\section{Sperm concentration}

Sperm concentration in the control, $5 \%$ SS, and $7 \%$ SS groups were identical (1.81-2.19 $\mathrm{x}$ $10^{9}$ sperm $\mathrm{mL}^{-1}$ ) during the adaptation period. This result was equivalent to the sperm concentration of $2.07 \times 10^{9}$ sperm $\mathrm{mL}^{-1}$ in Ho cocks published by Xuan et al. (2017) but higher than that of $0.95 \times 10^{9}$ sperm $\mathrm{mL}^{-1}$ in the same breed reported by Hue et al. (2015). The relative influence of various reproductive glands, management, and the extent to which the genetic potential is exploited may be responsible for this differentiation (Gee et al., 2004). Indeed, many studies have published higher sperm counts in other native chicken breeds. Tuncer et al. (2008) and Obidi et al. (2008) reported the mean sperm concentrations of $2.4 \times 10^{9}$ sperm $\mathrm{mL}^{-1}$ in Gerze cocks and 3.6 x $10^{9}$ sperm $\mathrm{mL}^{-1}$ in Shikabrown cocks, respectively. Siudzinska \& Lukaszewick (2008) stated sperm counts of $4.2 \times 10^{9}$ sperm mL ${ }^{-1}$ in the Black Minorcas breed and 4.7 x $10^{9}$ sperm $\mathrm{mL}^{-1}$ in White Crested Black Polish cocks. Sonseeda et al. (2013) reported the average sperm count of $4.3 \times 10^{9}$ sperm $\mathrm{mL}^{-1}$ in Thai indigenous chickens.

\section{Sperm motility}

The motility of spermatozoa of the Ho cocks in the control, $5 \% \mathrm{SS}$, and 7\% SS groups were similar $(67.50-70 \%)$ (Table 2). These values are in agreement with Peters et al. (2008) who reported that sperm motility in fresh semen of seven chicken breeds ranged from 60 to $90 \%$. However, these results were lower than the average value of sperm motility (80.64\%) in Ho cocks as published by Xuan et al. (2017) and that of sperm motility $(90 \%)$ in the same breed as reported by Doan et al. (2016). According to Sonseeda et al. (2013), sperm motility of Thai indigenous chickens was $88.2 \%$. Akhlaghi et al. (2014a) reported that a sperm motility of $80 \%$ was observed in Arabic chickens whilst this value in the Lingnam, Bangkok, and Kedu chicken breeds was $84 \%$.

\section{Mass movement}

The average mass movement scores of the Ho spermatozoa in the control, 5\% SS, and 7\% SS groups were 2.86-3.08. These values were lower than the results of Hue et al. (2015) and Xuan et al. (2017) who reported the average mass movement scores of Ho cocks were 3.3 and 3.8, respectively. Moreover, the values of the mass movement scores in Ho spermatozoa were lower than those in other native chickens. Nataamijaya et al. (2003) recorded the movement of spermatozoa in Arabian chicken had a score of 4.02 (as cited in Almahdi et al. (2014)). According to Sonseeda et al. (2013), the average mass movement score of Thai indigenous chicken spermatozoa was 4.3.

\section{Semen pH}

Donoghue \& Wishart (2000) stated that chicken semen $\mathrm{pH}$ often ranges from 6.0-8.0. Semen with a pH below 6.0 generally has 
decreased sperm motility, lactic acid production, and oxygen uptake, while a high semen $\mathrm{pH}$ (>8.0) increases the metabolic rate during in vitro semen storage (Donoghue \& Wishart, 2000). The correlation between semen $\mathrm{pH}$, sperm motility, and the metabolic rate was also reported by Masindi \& Mphaphathi (2016). The semen $\mathrm{pH}$ values of the Ho cocks in the control, $5 \%$ SS, and 7\% SS groups were 7.52-7.68 (Table 2) which are in accordance with the findings of the mentioned studies. The results in the current study are higher than the semen $\mathrm{pH}$ values of 7.44 and 7.20 in Ho cocks which were reported by Xuan et al. (2017) and Hue et al. (2015), respectively. Moreover, Almahdi et al. (2014) recorded lower average values of semen $\mathrm{pH}$ in four local chicken breeds including Lingnam (from China), Bangkok (from Thailand), Kedu (from Indonesia), and Arabic chickens (from Europe) which were 6.92, 6.98, 6.98 , and 7.04 , respectively.

\section{Abnormal spermatozoa}

Sperm abnormalities show disruptions of the spermatogenesis process (Bah et al., 2001). Toelihere (1985) supposed that sperm abnormalities vary from 5 to $20 \%$ (as cited in Almahdi et al. (2014)). Moreover, an abnormal spermatozoa rate higher than $25 \%$ will decrease fertility (Almahdi et al., 2014). The results showed that the percentage of abnormal spermatozoa in the control, 5\% SS, and 7\% SS groups were $10.90-11.42 \%$ (Table 2). These values in the current study are lower than those of $12.06 \%$ in Ho cocks (Doan et al., 2016), of $12.29 \%$ in Dong Tao cocks (Tham et al., 2017), and of $12.2 \%$ in Mia cocks (Tha, 2006).

\section{Semen quality characteristics during the experimental period}

To our knowledge, no previous studies have examined the effect of SS on the sperm quality of chickens. In general, our results proposed that sesame seeds had a positive influence on the semen quality characteristics of Ho cocks, significantly shown in the three parameters of semen volume, sperm concentration, and abnormal spermatozoa (Table 3). Semen ejaculate volume and sperm concentration were greater in the 7\% SS group compared with the control group $(\mathrm{P}<0.05)$, whereas the percentage of abnormal spermatozoa was lower $(\mathrm{P}<0.05)$. The control group showed the lowest semen volume and sperm concentration but the highest abnormal spermatozoa percentage. Other traits involving sperm motility, mass movement, and semen $\mathrm{pH}$ were not affected by the dietary treatments.

The effects of the treatments on specific traits during the ten weeks of the experimental period are presented in Figures 2-7. Semen volume was improved in the group fed $7 \% \mathrm{SS}$ compared to the control and 5\% SS groups, however, the differences were not significant across the ten weeks (Figure 2). Sperm concentration showed increasing values in the three groups throughout the study period, and the $7 \%$ SS group presented slightly higher values than the other groups, but the values were not considerably different (Figure 3). When comparing sperm concentration within each group, no variation for a considered group was observed during the period of semen analysis. Sperm motility showed no substantial differences between the three groups throughout the study period (Figure 4). Mass movement and semen $\mathrm{pH}$ showed the same patterns as sperm motility with no significant improvement in the treatment groups compared to the control group from weeks 1-10 (Figures 5 and 6, respectively). Concerning the abnormal spermatozoa trait, significant improvement in the group fed 7\% SS was observed compared to the control (Figure 7).

Chicken spermatozoa are rich in PUFAs which make them vulnerable to oxidative stress and lipid peroxidation (Surai et al., 1998; Eid et $a l ., 2006)$ and therefore, reduce their motility and fertility (Sanocka \& Kurpisz, 2004; Khan, 2011). To lessen chicken spermatozoa quality loss, different antioxidants have been investigated. Lycopene, a carotenoid existing in vegetables and fruits, showed a positive effect on semen volume and sperm concentration of broiler breeder males when supplemented in drinking water (Mangiagalli et al., 2010). Likewise, dietary ginger powder improved 
sperm forward motility and live sperm percentage, and decreased abnormal sperm in aged breeder cocks (Akhlaghi et al., 2014a). It was also previously reported that sperm concentration and sperm membrane integrity were significantly enhanced in aging Ross 308 breeder cocks fed dried apple pomace (Akhlaghi et al., 2014b). Moreover, positive effects were established on semen concentration, sperm forward motility and viability, semen volume,

Table 3. Semen quality characteristics during the experimental period

\begin{tabular}{|c|c|c|c|c|c|c|c|}
\hline \multirow[t]{2}{*}{ Parameter } & \multicolumn{2}{|c|}{$\begin{array}{l}\text { Control } \\
(n=60)\end{array}$} & \multicolumn{2}{|c|}{$\begin{array}{l}5 \% \text { SS } \\
(n=60)\end{array}$} & \multicolumn{2}{|c|}{$\begin{array}{l}7 \% \text { SS } \\
(n=60)\end{array}$} & \multirow[t]{2}{*}{ P-value } \\
\hline & Mean & SE & Mean & SE & Mean & SE & \\
\hline Semen volume (mL) & $0.82^{b}$ & 0.03 & $0.91^{\mathrm{ab}}$ & 0.04 & $1.02^{\mathrm{a}}$ & 0.04 & 0.000 \\
\hline Sperm concentration $\left(10^{9}\right.$ sperms $\left.\mathrm{mL}^{-1}\right)$ & $2.81^{b}$ & 0.17 & $3.17^{\mathrm{ab}}$ & 0.15 & $3.68^{\mathrm{a}}$ & 0.19 & 0.002 \\
\hline Sperm motility (\%) & 70.00 & 1.47 & 73.29 & 1.44 & 72.00 & 1.15 & 0.54 \\
\hline Mass movement & 3.26 & 0.03 & 3.22 & 0.05 & 3.31 & 0.06 & 0.59 \\
\hline Semen $\mathrm{pH}$ & 7.60 & 0.03 & 7.53 & 0.03 & 7.53 & 0.02 & 0.45 \\
\hline Abnormal spermatozoa (\%) & $11.04^{\mathrm{a}}$ & 0.12 & $10.74^{\mathrm{ab}}$ & 0.12 & $10.51^{b}$ & 0.12 & 0.01 \\
\hline
\end{tabular}

Note: Different superscripts within a row indicate a significant difference $(P<0.05)$.

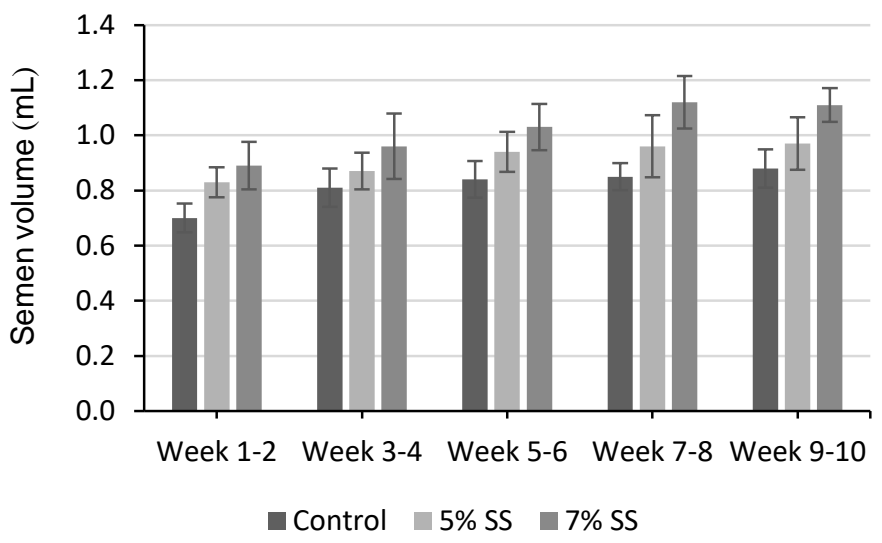

Figure 2. Semen volume $(\mathrm{mL})$ in the studied groups (control: no supplementation, $5 \%$ SS: receiving $5 \%$ of sesame seeds per cock and $7 \%$ SS: receiving $7 \%$ of sesame seeds per cock) during the 10 weeks of semen analysis. Values are expressed as means \pm SE.

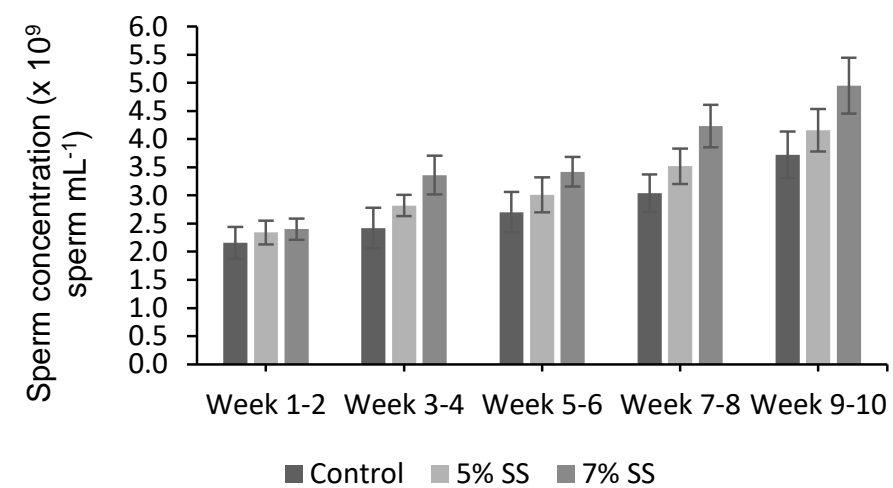

Figure 3. Sperm concentration ( $\times 10^{9}$ sperm $\mathrm{mL}^{-1}$ ) in the studied groups (control: no supplementation, $5 \%$ SS: receiving $5 \%$ of sesame seeds per cock, and $7 \%$ SS: receiving $7 \%$ of sesame seeds per cock) during the 10 weeks of semen analysis. Values are expressed as means $\pm \mathrm{SE}$. 


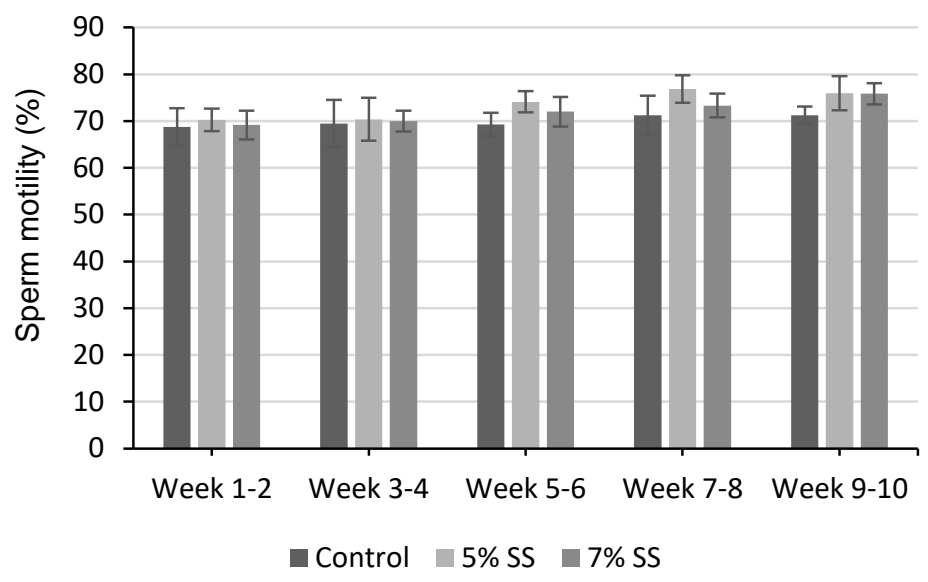

Figure 4. Sperm motility (\%) in the studied groups (control: no supplementation, $5 \%$ SS: receiving $5 \%$ of sesame seeds per cock, and $7 \%$ SS: receiving $7 \%$ of sesame seeds per cock) during the 10 weeks of semen analysis. Values are expressed as means $\pm \mathrm{SE}$.

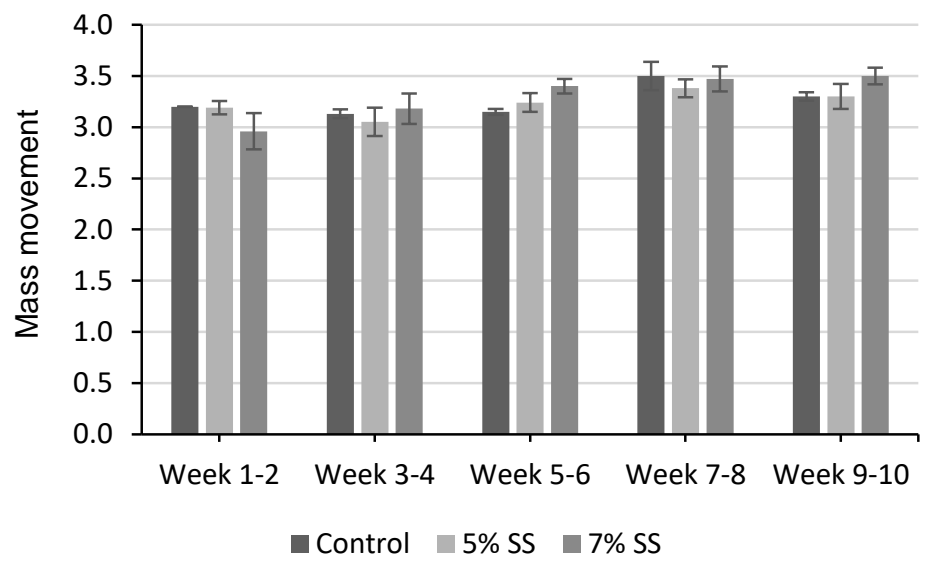

Figure 5. Mass movement (\%) in the studied groups (control: no supplementation, $5 \%$ SS: receiving $5 \%$ of sesame seeds per cock, and $7 \%$ SS: receiving $7 \%$ of sesame seeds per cock) during the 10 weeks of semen analysis.

Values are expressed as means $\pm \mathrm{SE}$.

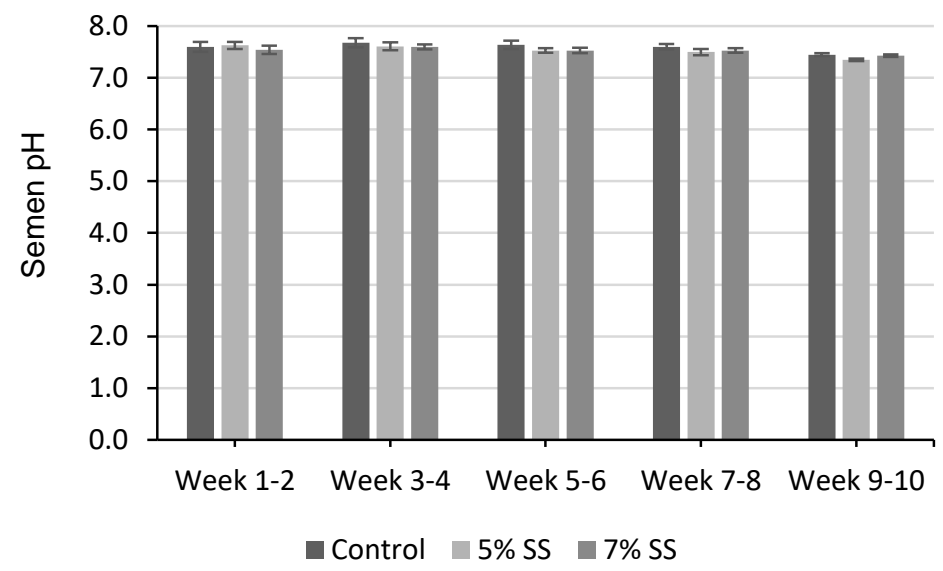

Figure 6. Semen pH in the studied groups (control: no supplementation, $5 \%$ SS: receiving $5 \%$ of sesame seeds per cock, and $7 \%$ SS: receiving $7 \%$ of sesame seeds per cock) during the 10 weeks of semen analysis. Values are expressed as means \pm SE. 


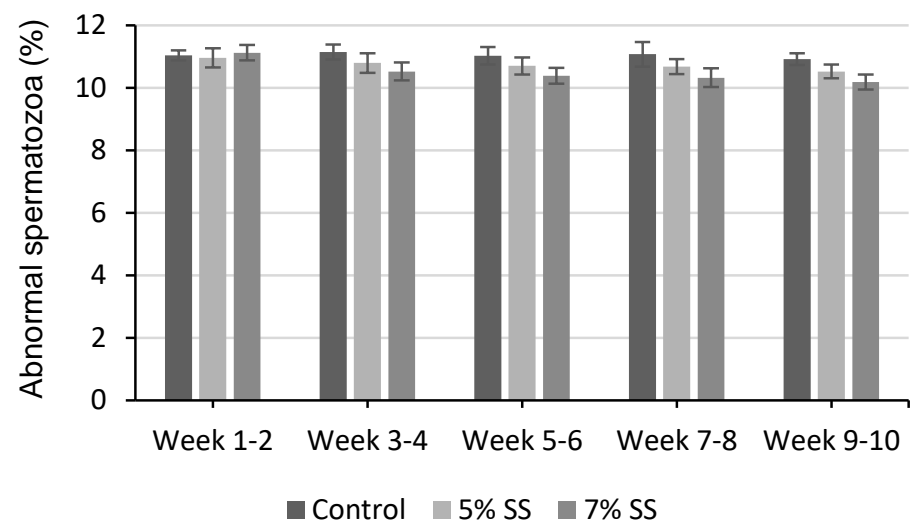

Figure 7. Abnormal spermatozoa (\%) in the studied groups (control: no supplementation, $5 \%$ SS: receiving $5 \%$ of sesame seeds per cock, and $7 \%$ SS: receiving $7 \%$ of sesame seeds per cock) during the 10 weeks of semen analysis. Values are expressed as means $\pm \mathrm{SE}$.

and sperm plasma membrane functionality when feeding rosemary leaf powder to breeder cocks (Borghei-Rad et al., 2017).

In the current study, the improvements observed are possibly associated with the high levels of minerals, vitamins, and antioxidant lignans (phytoestrogens) in sesame products (Shittu \& Bankole, 2007). Amini et al. (2013) reported that sesame seed intake $(30 \%$ of total diet) improved testicular parameters (number of epithelium cells and percentage volume of epithelial, lumen, and interstitial of these tubules, $\mathrm{P}<0.0001$ ), increased LH concentration ( $\mathrm{P}<0.03)$, increased fertility, and increased sperm production in male Wistar rats. According to Dimitrous (2006), sesame seeds and sesame lignans could also work to enhance the activity of vitamin $E$ to potentially protect low-density lipoproteins against oxidative damage. In addition, dietary vitamin $\mathrm{E}$ and organic selenium have been shown to have a synergistic effect in reducing lipid peroxidation and enhancing the antioxidative status of chicken semen, therefore, improving the spermatozoa count and number of live spermatozoa (Ebeid, 2012).

In our study, no significant differences were shown regarding sperm motility, mass movement, and semen $\mathrm{pH}$ between the group receiving 5\% SS and the group receiving 7\% SS per cock. These results propose that the effects of sesame seeds are articulated throughout spermatogenesis by providing antioxidant substances.

\section{Conclusions}

Semen quality characteristics were improved in Ho cocks by supplementing their diet with sesame seeds. Semen volume and sperm concentration were increased and abnormal spermatozoa were reduced in $\mathrm{Ho}$ chickens receiving $7 \%$ of sesame seeds in their diets. Therefore, dietary supplementation with sesame seeds is recommended in terms of malesavings to enhance the reproductive and economic efficiencies.

\section{Acknowledgments}

We would like to thank the AI Program between L'Académie de Recherche et d'Enseignement supérieur Commission de la Coopération au Développement (ARES-CCD) and Vietnam National University of Agriculture (VNUA), and VNUA (Grant No. T2018-02-13) for providing the financial support for this research.

\section{References}

Abou-Gharbia H. A., Shehata A. A. Y. \& Shahidi F. (2000). Effect of processing on oxidative stability and lipid classes of sesame oil. Food Research International. 33: 331-340. 
Abu M. M. T., Mohammad M. U. B., Raihana N. F., Nasrin S. J. \& Md. Bazlur B. R. M. (2013). Evaluation of semen quality among four chicken lines. IOSR Journal of Agriculture and Veterinary Science. 6: 7-13.

Akhlaghi A., Ahangari Y. J., Navidshad B., Pirsaraei Z. A., Zhandi M., Deldar M. H., Rezvani R., Dadpasand M., Hashemi S. R., Poureslami R. \& Peebles E. D. (2014a). Improvements in semen quality, sperm fatty acids, and reproductive performance in aged Cobb 500 breeder roosters fed diets containing dried ginger rhizomes (Zingiber officinale). Poultry Science. 93: 1236-1243.

Akhlaghi A., Jafari Ahangari Y., Zhandi M. \& Peebles E. D. (2014b). Reproductive performance, semen quality, and fatty acid profile of spermatozoa in senescent broiler breeder roosters as enhanced by the long-term feeding of dried apple pomace. Animal Reproduction Science. 147: 64-73.

Almahdi A. B., Ondho Y. S. \& Sutopo D. (2014). Comparative Studies of Semen Quality on Different Breed of Chicken in Poultry Breeding Center Temanggung-Central Java. International Refereed Journal of Engineering and Science (IRJES). 3(2): 94103.

Amini M. J., Hassani B. H., Nikzad H., Taherian A. \& Salehi M. (2013). Effect of Diet Contains Sesame Seed on Adult Wistar Rat Testis. International Journal of Morphology. 31: 197-202.

Ax R. L., Dally M., Didion B. A. \& Lenz R. W. (2000). Semen evaluation. In: Hafez B. \& Hafez E. S. E. Reproduction in Farm Animals ( $7^{\text {th }}$ ed.). Philadelphia: Lippincott Williams \& Wilkins. DOI: 10.1002/9781119265306.ch25.

Bah G. S., Chaudhari S. U. R. \& Al-Amin J. D. (2001). Semen Characteristics of Local Breeder Cocks in the Sahel Region of Nigeria. Revue d'Elevage et de Médecine Vétérinaire des Pays Tropicaux. 54(2): 153-158.

Biswas A., Mohan J. \& Sastry K. V. H. (2009). Effect of higher dietary vitamin $\mathrm{E}$ concentrations on physical and biochemical characteristics of semen in Kadaknath cockerels. British Poultry Science. 50: 733-738.

Borghei-Rad S. M., Zeinoaldini S., Zhandi M., Moravej H. \& Ansari M. (2017). Feeding rosemary leaves powder ameliorates rooster age-related subfertility. Theriogenology. 101: 35-43.

Dimitrous B. (2006). Sources of natural phenolic antioxidants. Trends in Food Science and Technology. 17: 505-512.

Doan B. H., Tuan H. A., Hang D. L. \& Thinh N. H. (2016). Effects of artificial insemination methods on reproductive performance of Ho breed of chicken. Vietnam Journal of Agricultural Sciences. 14: 727 -
733 (in Vietnamese with English abstract).

Donoghue A. M. \& Wishart G. J. (2000). Storage of poultry semen. Animal Reproduction Science. 62: 213-232.

Duy N. V., Moula N., Luc D. D., Dang P. K., Hiep D. T., Doan B. H., Ton V. D. \& Farnir F. (2015). Ho Chicken in Bac Ninh Province (Vietnam): From an Indigenous Chicken to Local Poultry Breed. International Journal of Poultry Science. 14(9): 521528.

Ebeid T. A. (2012). Vitamin E and organic selenium enhances the antioxidative status and quality of chicken semen under high ambient temperature. British Poultry Science. 53: 708-714.

Eid Y., Ebeid T. \& Younis H. (2006). Vitamin E supplementation reduces dexamethasone-induced oxidative stress in chicken semen. British Poultry Science. 47: 350-356.

Gee G. F., Bertschinger H., Donoghue A. M., Blanco J. \& Soley J. (2004). Reproduction in Nondomestic Birds: Physiology, Semen Collection, Artificial Insemination and Cryopreservation. Avian and Poultry Biology Reviews. 15: 47-101.

Gharby S., Harhar H., Bouzoubaa Z., Asdadi A., El Yadini A. \& Charrouf Z. (2017). Chemical characterization and oxidative stability of seeds and oil of sesame grown in Morocco. Journal of the Saudi Society of Agricultural Sciences. 16: 105-111.

Hue D. T., Luc D. D., Dung N. T., Thinh N. H. \& Ton V. D. (2015). Semen quality of Ho chicken and some affected factors. Conference of Sustainable Livestock Development Hanoi: Agricultural University Press. 17 (in Vietnamese with English abstract).

Jafari A. Y., Parizadian B. \& Zamani M. (2013). The impact of organic selenium supplementation on rooster semen quality in liquid condition. Poultry Science Journal. 1(1): 23-31.

Khan R. U. (2011). Antioxidants and poultry semen quality. World's Poultry Science Journal. 67: $297-$ 308.

Lake P. (1962). Artificial Insemination in poultry. In: Maile J. P. e. (Ed.). The semen of animals and artificial insemination. Bucks, England: Commonwealth Agriculture Bureau.

Mangiagalli M. G., Martino P. A., Smajlovic T., Guidobono Cavalchini L. \& Marelli S. P. (2010). Effect of lycopene on semen quality, fertility and native immunity of broiler breeder. British Poultry Science. 51: 152-157.

Masindi L. \& Mphaphathi M. M. (2016). The characterisation and cryopreservation of Venda chicken semen. Asian Pacific Journal of Reproduction. 5(2): 132-139.

Min Y., Sun T., Niu Z. \& Liu F. (2016). Vitamin C and 
vitamin E supplementation alleviates oxidative stress induced by dexamethasone and improves fertility of breeder roosters. Animal Reproduction Science. 171: 1-6.

Obidi J. A., Onyeanusi B. I., Rekwot P. I., Ayo J. O. \& Dzenda T. (2008). Seasonal variations in seminal characteristics of characteristics of Shikabrown breeder cocks. International Journal of Poultry Science. 7: 1219-1223.

Pathak N., Rai A. K., Kumari R. \& Bhat K. V. (2014). Value addition in sesame: A perspective on bioactive components for enhancing utility and profitability. Pharmacognosy reviews. 8(16): 147-155.

Peters S. O., Shoyebo O. D., Ilori B. M., Ozoje M. O., Ikeobi C. O. N. \& Adebambo O. A. (2008). Semen quality traits of seven strain of chickens raised in the humid tropics. International Journal of Poultry Science. 7: 949-953.

Sanocka D. \& Kurpisz M. (2004). Reactive oxygen species and sperm cells. Reproductive Biology and Endocrinology. 2: 12.

Shittu R. K. \& Bankole M. N. (2007). Sesame leaves intake improve and increase epididymal spermatocytes reserve in adult male Sprague Dawley rat. Scientific research and essays. 2: 319-324.

Siudzinska A. \& Lukaszewick E. (2008). The effect of breed on freezability of semen of fancy fowl. Animal Science Papers and Reports. 4: 331-340.
Sonseeda P., Vongpralub T. \& Laopaiboon B. (2013). Effects of Environmental Factors, Ages and Breeds on Semen Characteristics in Thai Indigenous Chickens: A One-year Study. Thai Journal of Veterinary Medicine. 43(3): 347-352.

Surai P. F., Cerolini S., Wishart G. J., Speake B. K., Noble R. C. \& Sparks N. H. (1998). Lipid and antioxidant composition of chicken semen and its susceptibility to peroxidation. Poultry and Avian Biology Reviews. 9: 11-23.

Tha D. D. (2006). Artificial insemination technology for animals. Labor Social Publishing House, Hanoi (in Vietnamese).

Tham L. T., Thu D. V., Binh D. V., Khoi T. X., Hue L. T., Thai N. X. \& Binh D. V. (2017). Assessment of semen quality and artificial insemination for Dong Tao chicken. Vietnam Journal of Agricultural Sciences. 15(6): 755-763 (in Vietnamese with English abstract).

Tuncer P. B., Kinet H. \& Ozdogan N. (2008). Evaluation of some spermatological characteristics in Gerze cocks. Ank Univ Vet Derg. 55: 99-102.

Xuan N. T., Duy N. V., Hue D. T., Luc D. D. \& Ton V. D. (2017). Fertilizing ability of Ho cock semen by different insemination doses and dilution rates. International Conference on: Animal production in Southeast Asia current status and future. Agricultural University Press, Hanoi, Vietnam. 48-57. 